lymphoma, or Brill-Symmers syndrome. They emphasized that only consideration of several features could enable the distinction to be made, and they noted as well that the reactive hyperplasia tended to be localized, whereas the lymphoma tended to be generalized. Therapeutically the enlarged masses of lymph nodes produced by follicular lymphoma respond well to radiotherapy or to chemotherapy, and such treatment will also reduce nodes later found to be non-neoplastic. To-day, when thoracotomy can be undertaken in centres with proper modern facilities, the risk of operative removal of such a mediastinal mass as occurred in the case reported here may well be worth while; but if physicians elsewhere meet such a case treatment with radiotherapy or even chemotherapy might be adequate.

\section{Thymectomy and Myasthenia Gravis}

The first well-documented association of a thymic tumour with myasthenia gravis was reported in 1901 by L. Loquer and C. Weigert, ${ }^{1}$ but H. R. Viets and R. S. Schwab ${ }^{2}$ state that two years before this Oppenheim had mentioned the association in a paper in which he showed that there were no pathological changes in the nervous system in myasthenia gravis. The first thymectomy for myasthenia was performed by Sauerbruch in $1911^{3}$ on a patient who also suffered from thyrotoxicosis. Some improvement in the myasthenia was noted. In $1937^{45}$ the same surgeon operated on two myasthenic patients who had thymic tumours, but both patients died of mediastinitis.

But it was A. Blalock ${ }^{6}$ in 1936 who first showed the value of thymectomy in the treatment of myasthenia. As well as operating on patients with thymic tumours he also removed the organ from patients without a tumour. In 1942 Sir Geoffrey Keynes $^{7}$ performed the first thymectomy for myasthenia in Great Britain, and it is as a result of his work on the subject that the value of the operation in selected cases of myasthenia has been established. From an early stage he emphasized the importance of considering separately patients with and without a tumour when assessing the results of operation. Tumours of the thymus are present in about $15 \%$ of myasthenic patients, ${ }^{8}$ and with careful radiological techniques ${ }^{9}$ if a tumour is present it can usually be seen.

In 1958 J. A. Simpson ${ }^{10}{ }^{11}$ surveyed Keynes's results in 294 operated patients and compared them with those obtained in 110 patients who had not been operated on. He found that fewer women died of myasthenia if their thymus had been removed than would be expected if they were treated with drugs alone. Moreover, thymectomy also increases the number of women very greatly improved ten years or more after the onset of the illness. In the smaller number of male patients similar trends were found, but the beneficial results of

\footnotetext{
1 Loquer, L., and Weigert, C., Neurol. Zbl., 1901, 20, 594.

Viets, H. R., and Schwab, R. S., Thymectomy for Myasthenia Gravis, 1960. Charles C. Thomas, Springfield, IIl.

schumacher and Roth, Mitt. Grenzgeb. Med. Chir., 1913, 25, 746.

- Adler, H., Arch. Klin. Chir., 1937, 189, 529.

s Obedtsch, R. A., Arch. path. Anat., 1937, 300, 319.

Blalock, A., Mason, M. F., Morgan, H. J., and Riven, S. S., Ann. Surg., 1939, 110, 544.

' Keynes, G., Brit. F. Surg., 1946, 33, 201.

(1955, 42, 449.

Harper, R. A., Kemp, and Guyer, P. B., Clin. Radiology, 1965, 16, 97

Simpson, J. A., Brain, 1958, 81, 112

Brit. med. F., 1959, 1, 288.

Henson, R. A., Stern, G. M., and Thompson, V. C., Brain, 1965 ,
}

\section{A Problem in Bacterial Endocarditis}

Sensitivity to penicillin in a patient with bacterial endocarditis presents a difficult problem. The antibiotic or combination of them used in treating this disease must be fully bactericidal, or eventual relapse is almost certain. Bactericidal antibiotics other than penicillin are less effective against streptococci and more toxic. Vancomycin might be the best choice, but it is also difficult to administer. If penicillin must be given at all costs, there are three ways in which this can be made possible. One is desensitization, but this is uncertain, time-consuming, and hazardous. Another is to protect the patient with an \footnotetext{
Maslansky, L., and Sanger, M. D., Antibiot. and Chemother., 1952, 2,

2 Balme, H. W., and Dormer, A. E.,.Brit. med. F., 1954, 1, 500

3 Raper, A. J., and Kemp, V. E., New Engl. ¥. Med., 1965, 273, 297.
} 